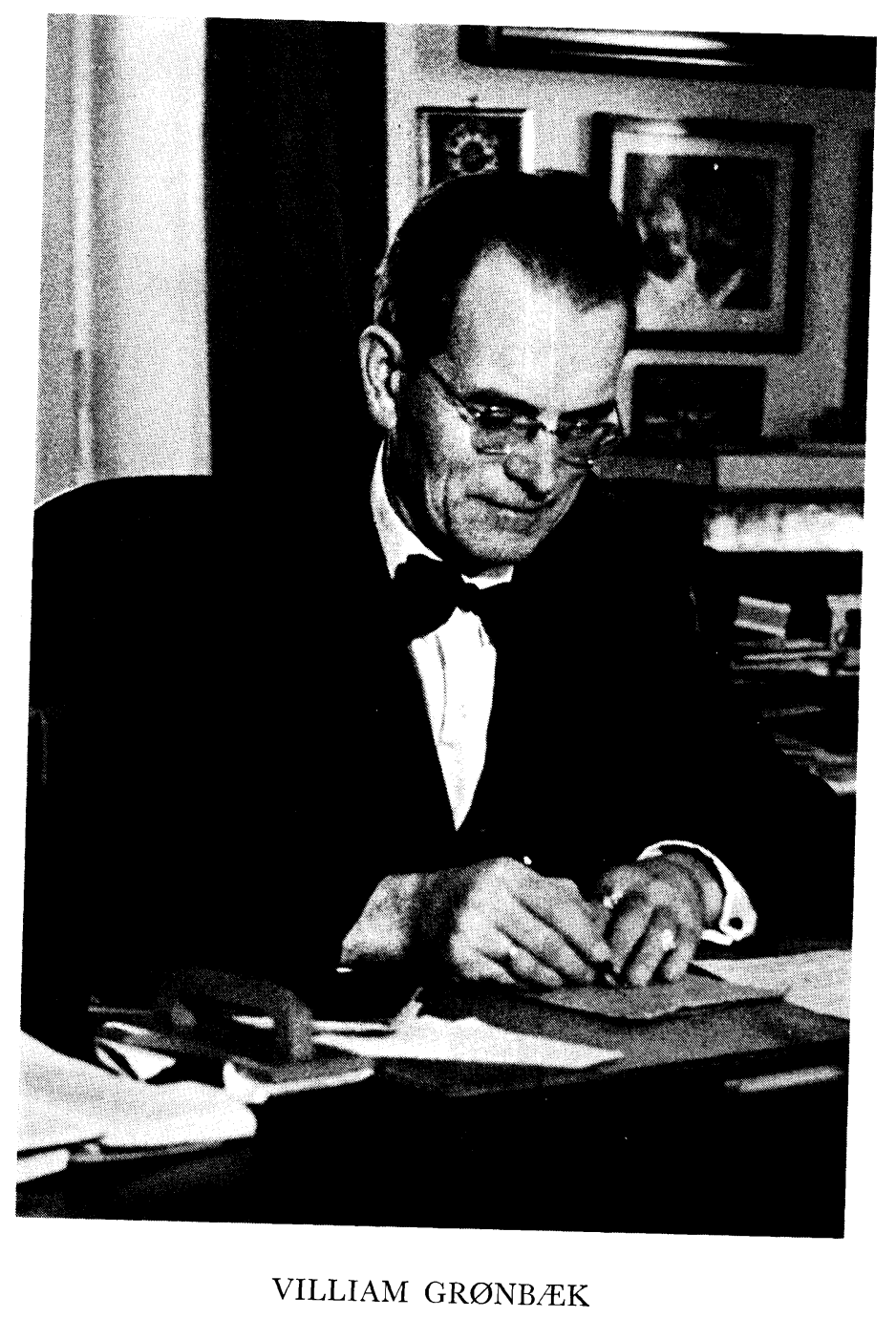




\title{
Villiam Grønbæk
}

\author{
21. december I897-4. april 1970.
}

Med Villiam Grønbcek er en af pionererne i Grundtvig-Selskabet og den nyere Grundtvig-forskning gået bort. Udtrykket pioner vil måske overraske nogle. Det umiddelbare indtryk, man havde af domprovsten i Ribe, var snarere, at han var en kontinuitetens værner, og forbindelsen med Grundtvig-selskabet har endnu flere vel glemt over formandskabet i Kirkeligt Centrum. Men det er et faktum, at det var Villiam Grønbæks og Ribe-biskoppen C. I. Scharlings Grundtvigstudier, der gav anledning til det møde af Grundtvigforskere i Ribe, hvorved Grundtvig-selskabet stiftedes 8. september i947. Med den største gæstfrihed og hjertelighed blev man modtaget af en studiefælle med et helt andet udgangspunkt og vel også et ganske andet mål, udelukkende fordi man havde fælles anliggende - og det viste sig, at der var fuldkommen enighed om det magtpåliggende $i$ at danne et forum for Grundtvigforskningen, uafhængigt af kirkelig observans, politisk tilhørsforhold og pædagogiske synspunkter. Samarbejdet med Scharling, der blev selskabets første formand, viste sig bl. a. i en oversigt over Scharlings forfatterskab i Ribe Stifts Aarbog 1952, der indirekte tegner et portræt - ikke blot af Scharling, men lige så meget af Grønbæk selv:

»Grundtvig læste forbi, hvad der ikke interesserede ham, og fandt ikke anledning til at drøfte de i bøgerne indeholdte problemer for drøftelsens skyld. Bekræftende, fordømmende, med sit eget standpunkt, hvis rigtighed altid stod for ham soleklart, som rettesnor tog han stilling til, hvad han læste, hvorved han let kom til at gøre en bog til genstand for uretfærdig bedømmelse.

Scharling læste paa en helt anden maade. Han gik ikke ud fra sit eget standpunkt, men levede sig ind i paagældende forfatters tankeverden, besjælet af trangen til at forstaa ham og hans tanker.« 
Nøjagtig det samme var rettesnoren for Villiam Grønbæks egne studier over »Psykologiske Tanker og Teorier hos Grundtvig«, der udkom i selskabets skriftserie I95I. Forarbejder var allerede gjort forinden mødet fire år før; men det fremgår direkte af forordet, at det videnskabelige samarbejde, mødet indledte, har haft væsentlig betydning for det færdige arbejde.

Som religionspsykolog havde det været naturligt for Grønbæk at tage Grundtvig op til kritisk undersøgelse, så meget mere som hans arbejde gik ud fra studiet af det psykologiske islæt i J. P. Mynsters forfatterskab. Men det gik helt anderledes, end man kunde vente. Det blev i stedet til en undersøgelse af Grundtvig som psykolog, der endnu venter på sin fortsættelse. P. G. Lindhardt fandt i sin anmeldelse i Grundtvig-Studier »nøgler til store dele af det religiøst-kristelige forfatterskab« i Grønbæks studier over såvel anelse og længsel som selvbevidsthed og erfaring: »meget dunkelt i grundtvigianismens historie bliver klart, når man agter på de af dr. Grønbæk kortlagte sammenhænge«, skriver han. »En mængde temmelig ubegribelig »bragesnak « får gennem dette arbejde en indre mening, som man ikke før har fået øje på, og selve grundtvigianismen - vor kirkehistories besynderligste sociologiske og psykologiske fænomen - bliver i sit forhold til Grundtvig mere gennemskuelig end før.« - Den fortsættelse af Grønbæks pionerarbejde, der hermed var lagt op til, er (trods K. E. Bugges studier over Grundtvigs skoletanker) stadig en uløst opgave, lige så påkrævet som i 1952 .

Årsagen ligger dels i, at Grundtvigs psykologiske tanker aldrig er blevet trykt $\mathrm{i}$ deres oprindelige form - Grønbæk måtte grave dem frem af hidtil ukendte efterladte manuskripter, - men dels også $i$, at kendskabet til de i Grundtvigs ungdom udbredte psykologiske tanker og teorier kræver en specialist af Villiam Grønbæks ydmyge forskertype. Man må især af den sidstnævnte grund beklage, at Grønbæk aldrig fulgte Lindhardts direkte opfordring til at fortsætte sit arbejde. - Det er nu engang en væentlig forudsætning for at forstå Grundtvigs psyke at vide, hvordan han selv så på den menneskelige psyke i almindelighed. Det gjorde Grønbæk.

William Michelsen 